\title{
Traditional medicinal plants used for the treatment of diabetes in rural and urban areas of Dhaka, Bangladesh - an ethnobotanical survey
}

\author{
Soeren Ocvirk ${ }^{1 \dagger}$, Martin Kistler ${ }^{1 \dagger}$, Shusmita Khan ${ }^{2}$, Shamim Hayder Talukder ${ }^{2}$ and Hans Hauner ${ }^{1 *}$
}

\begin{abstract}
Background: The usage of medicinal plants is traditionally rooted in Bangladesh and still an essential part of public healthcare. Recently, a dramatically increasing prevalence brought diabetes mellitus and its therapy to the focus of public health interests in Bangladesh. We conducted an ethnobotanical survey to identify the traditional medicinal plants being used to treat diabetes in Bangladesh and to critically assess their anti-diabetic potentials with focus on evidence-based criteria.

Methods: In an ethnobotanical survey in defined rural and urban areas 63 randomly chosen individuals (health professionals, diabetic patients), identified to use traditional medicinal plants to treat diabetes, were interviewed in a structured manner about their administration or use of plants for treating diabetes.

Results: In total 37 medicinal plants belonging to 25 families were reported as being used for the treatment of diabetes in Bangladesh. The most frequently mentioned plants were Coccinia indica, Azadirachta indica, Trigonella foenum-graecum, Syzygium cumini, Terminalia chebula, Ficus racemosa, Momordica charantia, Swietenia mahagoni.

Conclusion: Traditional medicinal plants are commonly used in Bangladesh to treat diabetes. The available data regarding the anti-diabetic activity of the detected plants is not sufficient to adequately evaluate or recommend their use. Clinical intervention studies are required to provide evidence for a safe and effective use of the identified plants in the treatment of diabetes.
\end{abstract}

Keywords: Ethnobotanical survey, Diabetes mellitus, Traditional medicinal plants, Evidence-based medicine, Bangladesh

\section{Introduction}

Bangladesh features a sub-tropical climate and low-lying landmass largely adjacent to extensive river deltas. The country comprises very fertile soils and is home to some rare ecosystems such as the Sundarbans mangrove forests. Given the fertile plains and high population density, the indigenous vegetation has mostly given way to cropland and extensive cultivation. Today, almost 60\% of the landmass is used for farming, which is a global maximum value. However, originally large parts of

\footnotetext{
* Correspondence: hans.hauner@tum.de

${ }^{\dagger}$ Equal contributors

${ }^{1}$ Else Kroener-Fresenius-Center for Nutritional Medicine, Klinikum rechts der Isar, 81675 Munich and ZIEL - Research Center for Nutrition and Food Sciences, Technische Universität München, 85350, Freising-Weihenstephan, Germany

Full list of author information is available at the end of the article
}

Bangladesh featured tropical forests and marshy jungle with highly biodiverse flora - being also an excellent source for medicinal plants.

The Bangladeshi traditional medicine is a unique conglomerate of different ethnomedical influences. Due to the geographic location and sociocultural characteristics of the country, it involves traditionally rooted elements influenced by local indigenous people and close-by Indian Ayurveda and Unani medicine [1,2]. Given its inexpensive, easily accessible and well-established health services, the use of traditional medicine is an integral part of public health services in Bangladesh with its providers being deeply embedded within the local community [3-5]. Recent data suggest that the utilization of traditional medicine health services in Bangladesh is widespread [6] and plays a crucial role in providing 
health care for poor people, people in rural areas and for tribal people [4,7-13].

In the context of using traditional medicinal plants for treating diabetes, extensive screening has been performed in many ethnomedical systems within the Indian subcontinent $[14,15]$. However, in Bangladesh the traditional medicinal plants that are used for the treatment of diabetes have not yet been studied in great detail. Therefore, these herbal remedies are important objects of research, especially in context of the virtually exploding prevalence of diabetes mellitus in Bangladesh. Although diabetes is more prevalent in urban areas [16,17], in rural communities prevalence rates for diabetes rose from $2.3 \%$ to $6.8 \%$ in between 1999 to 2004 [18].

A recent survey in Bangladesh demonstrated that in slum areas, $86 \%$ of female and $78 \%$ of male diabetic patients use either inadequate medical treatment or none [19]. In non-slum areas only $34 \%$ of female and male diabetic patients undergo adequate medical treatment [19] raising the question, whether herbal remedies of the traditional Bangladeshi medicine may offer a safe, effective and reasonable alternative therapy for diabetes. To address this question, an identification of the plants being used in Bangladesh for the treatment of diabetes is essential. We conducted an ethnobotanical survey in defined rural and urban areas of Bangladesh to document and evaluate which plants are used for the treatment of diabetes.

\section{Material and methods \\ Study area}

The study was performed in both an urban district of Dhaka, as well as a rural region adjoining to the city. The urban part was conducted in Dhaka, which is the capital of Bangladesh and has an area of $304 \mathrm{~km}^{2}$. According to the 2008 estimate of the Bangladesh Bureau of Statistics, Dhaka has a metropolitan population of about $12.8 \mathrm{~m}$ inhabitants, of which most are of Bengali origin. Although the direct biodiversity in the city is obviously quite low, Dhaka - with its offer of labor and infrastructure - causes a continuous migration of new residents from all over Bangladesh. This leads to a diverse background of the inhabitants and was a major reason for conducting the survey in several thanas (subdistricts) in Dhaka on the professional informant side. For the interviews with diabetic patients we focused predominantly on a previously recruited cohort residing in the Mirpur subdistrict of Dhaka. The rural part of the survey was conducted in Manikganj, which is a part of Dhaka division. It is bounded by the Dhaka district on the east and south and bordered by the Jamuna and Padma River. The Manikganj district has an area of $1379 \mathrm{~km}^{2}$ and a population of $1.3 \mathrm{~m}$ inhabitants. Being a former subdivision of the Dhaka district, it features a rural environment with smaller towns and a lower population density than the urban areas of Dhaka.

\section{Ethnobotanical data collection and type of data collected}

This study adhered to the research guidelines and ethical protocols of the Technical University of Munich. The aim of the study was to qualitatively identify traditional medicinal plants known and accessible by the Bangladeshi population. For this purpose, a dialogue with local political and health service authorities was initiated for authorization as well as support. To obtain the most valuable information in a reasonable sample size, interviews of key informants were performed. Altogether 63 interviews were conducted, of which 29 were attributed to rural and 34 to urban regions. To cover a diverse spectrum of informants, different informant groups were defined for participating in the study. From these informant groups, key informants were randomly chosen out of a pool of knowledgeable persons (Table 1). It is noteworthy that the sample size of informants participating in this study was limited and not representative for the study groups or regional distribution, so that quantitative conclusions are not feasible. However, to screen the data obtained in this study the overall frequency of citation of plants was assessed and is indicated in the results (Table 2).

Interviews were conducted in the Bengali language and based on a semi-structured question form with answers recorded. Informed consent was obtained from the participants for the publication of this report. The questionnaire was designed to gather information on

Table 1 Sample size and demographic data of key informants

\begin{tabular}{|c|c|c|c|c|}
\hline Informant group & No of persons (urban/rural) & Gender (female/male) & Age & Professional experience \\
\hline Diabetic patients & $9 / 9$ & $6 / 12$ & $53(35-68)$ & - \\
\hline Traditional healers (Kabiraj) & $5 / 5$ & $1 / 9$ & $59(25-82)$ & $26(2-50)$ \\
\hline Indigenous medicine companies ${ }^{a}$ & $5 /-$ & $0 / 5$ & $50(25-66)$ & $8(3-14)$ \\
\hline Private indigenous healing centers & $5 / 5$ & $0 / 10$ & $42(25-57)$ & $11(1-23)$ \\
\hline Indigenous doctors ${ }^{b}$ & $5 / 5$ & $1 / 9$ & $42(30-65)$ & $8(1-25)$ \\
\hline Allopathic doctors & $5 / 5$ & $2 / 8$ & $45(39-52)$ & $9(4-20)$ \\
\hline
\end{tabular}

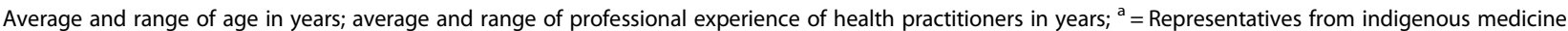

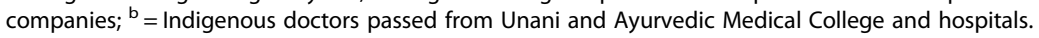


Table 2 List of medicinal plants used in traditional medicine for the treatment of diabetes in Bangladesh

\begin{tabular}{|c|c|c|c|c|c|}
\hline $\begin{array}{l}\text { Botanical name } \\
\text { (Voucher specimen ID) }\end{array}$ & Family & Local Name & Plant parts used & Stage of maturity & $\begin{array}{l}\text { Frequency } \\
\text { of citation }\end{array}$ \\
\hline Achyranthes aspera L. (BD-01) & Amaranthaceae & Upat Lengra & Root, whole plant & M & 0.85 \\
\hline Adiantum capillus-veneris L. (BD-02) & Adiantaceae & Hanglapudi, Gobalelota & Seed & M & 0.8 \\
\hline Allium sativum L. (BD-03) & Amaryllidaceae & Rôsun & Root, whole plant & M & 1.6 \\
\hline $\begin{array}{l}\text { Andrographis paniculata Wall. } \\
\text { ex Nees (BD-04) }\end{array}$ & Acanthaceae & Kālmegh & Leaf, whole plant & M & 0.85 \\
\hline Asparagus racemosus L. (BD-05) & Asparagaceae & Sotomuli & Root & $M, F$ & 1.6 \\
\hline Azadirachta indica A. Juss. (BD-06) & Meliaceae & Neem & Bark, leaf, seed & $M, F$ & 8.4 \\
\hline Bunium persicum Bois. (BD-07) & Apiaceae & Kalo Jeera & Seed, whole plant & M & 1.6 \\
\hline Centella asiatica L. (BD-08) & Apiaceae & Thankuni & Leaf & M & 0.8 \\
\hline Coccinia indica W.\&A. (BD-09) & Cucurbitaceae & Kundri, Telachuka & Fruit, leaf, root, whole plant & $M, F, P m$ & 16.95 \\
\hline Cynodon dactylon (L.) Pers. (BD-10) & Poaceae & Durba & Leaf, whole plant & $M, F$ & 1. \\
\hline Datura stramonium L. (BD-11) & Solanaceae & Dhotura & Seed & M & 0.8 \\
\hline Eclipta alba L. (BD-12) & Asteraceae & Bringoraj, Kalokeshi & Leaf & M & 0.8 \\
\hline Ficus benghalensis L. (BD-13) & Moraceae & Bot, Kathali Pata Bot & Leaf & $M, F$ & 1.6 \\
\hline Ficus racemosa L. (BD-14) & Moraceae & Joiggidumur & Bark, fruit & $\mathrm{M}, \mathrm{Pm}$ & 4.2 \\
\hline Gymnema sylvestre R. Br. (BD-15) & Asclepiadaceae & Medhasingi, Gorshar & Whole plant & M & 0.8 \\
\hline Heliotropium indicum L. (BD-16) & Boraginaceae & Hatisur & Leaf & M & 0.8 \\
\hline Hemidesmus indicus L. R. Br. (BD-17) & Apocynaceae & Anantomul & Root & $\mathrm{F}$ & 0.8 \\
\hline Lagerstroemia speciosa (L.) Pers. (BD-18) & Lythraceae & Jarul & Leaf & M & 2. \\
\hline Mangifera indica L. (BD-19) & Anacardiaceae & Aam & Seed & M & 0.8 \\
\hline Mimosa pudica L. (BD-20) & Fabaceae & Lojjaboti, Sada Lojjaboti & Whole plant & M & 0.85 \\
\hline Momordica charantia L. (BD-21) & Cucurbitaceae & Kôrola & Fruit, leaf, whole plant & $M, F$ & 4.2 \\
\hline Musa sapientum L. (BD-22) & Musaceae & Kôla & Fruit & M & 0.8 \\
\hline Ocimum sanctum L. (BD-23) & Lamiaceae & Krisno Tulshi, Kalo Tulshi & Whole plant & $M, F$ & 0.8 \\
\hline Phyllanthus emblica L. (BD-24) & Phyllanthaceae & Amloki & Fruit, seed, whole plant & $M, F$ & 3.3 \\
\hline Swertia chirata L. (BD-25) & Gentianaceae & Chirota & Root & - & 0.8 \\
\hline Swietenia mahagoni Jacq. (BD-26) & Meliaceae & Mahogany & Seed & $M, F$ & 4.2 \\
\hline Syzygium cumini (L.) Skeels (BD-27) & Myrtaceae & Jam & Leaf, seed & $M, F$ & 7. \\
\hline Tamarindus indica L. (BD-28) & Fabaceae & Tetul & Seed & M & 1.6 \\
\hline Terminalia arjuna W.\&A. (BD-29) & Combretaceae & Arjun & Seed & M & 0.8 \\
\hline Terminalia bellirica L. (BD-30) & Combretaceae & Bohera, Jonglee Bohera & Seed & $M, F$ & 3. \\
\hline Terminalia chebula Retz. (BD-31) & Combretaceae & Horituki & Seed & $M, F$ & 5.0 \\
\hline $\begin{array}{l}\text { Tinospora cordifolia Hook. } \\
\text { F. \& Thoms. (BD-32) }\end{array}$ & Menispermaceae & Gulancha lota & Bark, leaf, root, whole plant & M & 3.3 \\
\hline Trigonella foenum-graecum L. (BD-33) & Fabaceae & Methi & Seed, whole plant & $M, F$ & 8.4 \\
\hline Vernonia anthelmintica Willd. (BD-34) & Asteraceae & Somraj & Whole plant & M & 0.85 \\
\hline Vinca rosea L. (BD-35) & Apocynaceae & Golapi Noyontara & Leaf & $\mathrm{F}$ & 0.8 \\
\hline Vitex negundo L. (BD-36) & Lamiaceae & Nirgundi, Nishinda, Samalu & Leaf & M & 0.8 \\
\hline Withania somnifera (L.) Dunal (BD-37) & Solanaceae & Aswagandha & Leaf, root, whole plant & $M, F$ & 2. \\
\hline
\end{tabular}

Alphabetically listed with plant parts used (listed alphabetically); stage of maturity of plant when being used ( $M=$ mature, $F=$ fresh, $P m=$ premature); frequency of citation by informants.

social status and education of the informant, general knowledge about diabetes (and its diagnosis), access to allopathic medicine, and medicinal plants used in the therapy of diabetes. Formulations of plants were not included in this survey. Every key informant was interviewed once. Medicinal plants being mentioned by the informant were recorded with local names and photographed. Whenever possible, informants were 

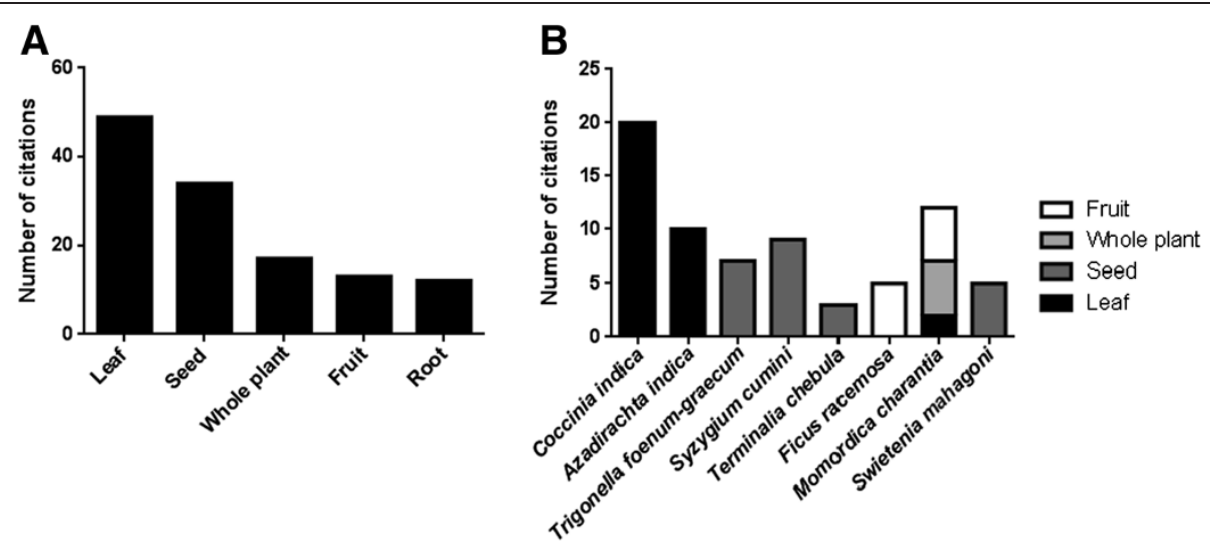

Figure 1 Parts used for the treatment of diabetes from all plants (A) and the most frequently mentioned plants (B). Multiple answers possible, some informants did not mention any specific plant parts.

asked to show or collect the plants they use for the treatment of diabetes. The documented plants and samples were dried, stored and identified with the help of a botanist.

\section{Data analysis}

The frequency of citation was calculated to assess the incidence of one particular plant species used for the treatment of diabetes in relation to the overall citations for all plants. The frequency of citation for a plant species was calculated as follows: Frequency of citation for a particular species $=($ Number of citations for that particular species/Number of all citations for all species) "100. For the most mentioned medicinal plants of the survey, a literature search was performed with special focus on diabetes-related clinical data.

\section{Results}

The 63 conducted key informant interviews of the ethnobotanical survey revealed 37 different plants that were mentioned by informants for anti-diabetic treatment individually or combined with other plants (Table 2). Regarding the overall frequency of citation, the most cited plants were Coccinia indica, Azadirachta indica, Syzygium cumini, Trigonella foenum-graecum, Terminalia chebula, Ficus racemosa, Momordica charantia and Swietenia mahagoni, suggesting a prominent role of these plants in the herbal treatment of diabetes.

Leaves and seeds at a defined stage of maturity were most frequently cited to be used for treatment or preparation of the traditional medicine (Figure 1A). Interestingly, plant parts used from the most frequently mentioned plants were consistent with the exception of Momordica charantia (Figure 1B).

To receive an impression of regional availability of the top-mentioned plants, the number of citations in urban and rural areas was compared. Though only a few more informants were interviewed in urban areas (Table 1), the number of citations by urban informants prevails considerably for most plants (Figure 2). Trigonella foenum-graecum and Momordica charantia were exclusively mentioned by urban informants.

Finally, the most frequently mentioned plants were analyzed regarding times mentioned by the relevant informant groups for herbal treatment of diabetes. Admittedly quantitative comparisons between the groups were not feasible due to overall low numbers of informants and the high number of diabetic patients outnumbering all other groups. However, all top-mentioned plants were known by a minimum of three informant groups, suggesting a broad propagation of these plants within the different diabetes-related groups (Figure 3). The most mentioned medicinal plant, Coccinia indica, was also most prevalently used in the diabetic patients group highlighting its prominent role in herbal treatment of diabetes in the study area. In contrast, Coccinia indica

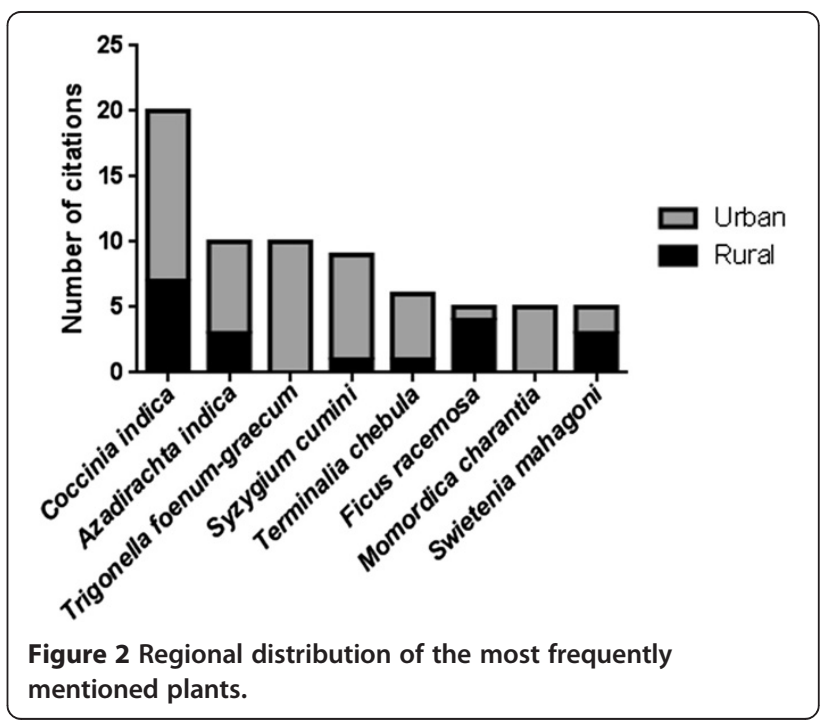




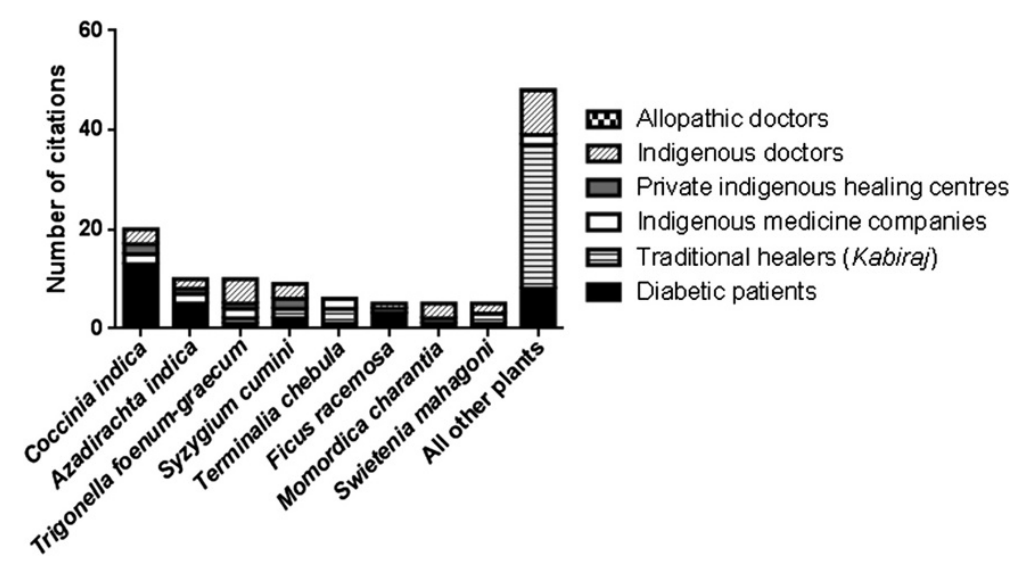

Figure 3 Citation of most frequently mentioned plants related to informant groups.

was not cited by the traditional healer (Kabiraj) informant group. Interestingly, most of the not top-mentioned plants were cited by the Kabiraj informant group (Figure 3).

\section{Discussion}

Overall, the survey revealed 37 medicinal plants belonging to 25 families that are used to treat diabetes in Bangladesh. Due to limited sample size, we focused this discussion on the most frequently mentioned plants.

Regarding all identified plants, leaves and seeds were the major plant parts used, which is in agreement with other studies $[12,20,21]$. The collection and processing of leaves and seeds is easy [21], and does not damage the plant substantially as compared to the collection of roots or the whole plant $[22,23]$. Leaves and seeds may contain or accumulate the pharmacologically active agents of plants. For example, these were reported for the seeds of Trigonella foenum-graecum [24,25] and Syzygium cumini [26] and the leaves of Coccinia indica [27-29] and Azadirachta indica [30].

A recent survey recorded plant parts similar to our study for Coccinia indica, Azadirachta indica, Syzygium cumini, Trigonella foenum-graecum, Terminalia chebula and Momordica charantia used in the treatment of diabetes by traditional health practitioners in Bangladesh [12]. In contrast to our study, Kadir et al. mentioned bark and root of Ficus racemosa to be used as medicinal plant component. Although most studies show antidiabetic properties for the bark of Ficus racemosa $[31,32]$, anti-diabetic agents were also isolated from its fruits [33]. Interestingly, Swietenia mahagoni was not reported as a medicinal plant used for the treatment of diabetes in Bangladesh. Since Swietenia mahagoni is not indigenous to Bangladesh, it may not be a common traditional medicinal plant for this area. However, it was cited by indigenous doctors (Ayurveda/Unani) as well as traditional Kabiraj healers in this survey. Recent reports emphasize the hypoglycemic and anti-oxidant activity of Swietenia mahagoni bark and seed extracts [34,35].

Regarding the regional distribution of plants, the most top-mentioned plants seem to be similarly available in urban and rural regions. Higher availability of plants in urban regions may reflect the role of Dhaka as socio-economic and commercial center of the country. Trigonella foenum-graecum and Momordica charantia were only mentioned by urban informants, suggesting a general low local availability of these plants in the rural surroundings of Dhaka. However, Trigonella foenumgraecum [24] and Momordica charantia [36,37] are widely available at local markets in Bangladesh.

Coccinia indica was mentioned by one third of all informants for being used as an anti-diabetic agent. In Bangladesh, Coccinia indica is well-known as an ayurvedic medicinal plant and is used for the treatment of diabetes $[12,27,28]$. It seems to be largely available in the area of Dhaka, since it was mentioned by most informants from the diabetic patients group. Leaves of Coccinia indica showed hypoglycemic effects in several animal studies [29,36,38,39] and small human intervention trials $[28,40,41]$. Though showing promising preliminary results, the anti-diabetic efficacy of Coccinia indica is not convincing due to the lack of solid evidence from extensive clinical intervention studies.

Momordica charantia is an edible vegetable commonly known as bitter gourd. It is widely available in Bangladesh and also well-known as an agent with several anti-diabetic effects $[36,37,42,43]$. Numerous studies revealed anti-hyperglycemic effects for its fruits in experimental animal studies of induced diabetes [36,37,44-46], but also the leaves, stem and seeds were reported to be used for anti-diabetic treatment [12]. Conflicting results were reported by small clinical trials; only modest hypoglycemic effects less distinct than for metformin were shown in type 2 diabetes mellitus patients [47], and no effect on the levels of plasma insulin and glucose was 
detectable in obese men [48], revealing the inconsistent outcomes for Momordica charantia regarding clinical trials [49].

Several small preliminary clinical studies investigating the effect of seed extracts of Trigonella foenum-graecum revealed a significantly reduced insulin resistance [50] and improved fasting and postprandial blood glucose levels $[51,52]$ in diabetic patients. Isolated compounds of fenugreek, when administered in addition to sulfonylureas, also showed an improved anti-diabetic action compared to sulfonylureas alone in diabetic patients [53]. Since there are relatively many, but rather small human clinical trials available for fenugreek, it is one of the most interesting candidate plants for effective and safe anti-diabetic therapy.

Azadirachta indica is a common medicinal plant for tribal people in Bangladesh [12,13]. Anti-hyperglycemic effects in normal or diabetes-induced animal models were shown for leaf extracts of Azadirachta indica $[30,39,54,55]$. Seed extracts had significant hypoglycemic activity in a small cohort of type 2 diabetes patients [56].

For Ficus racemosa, few animal studies report blood glucose lowering activity [31-33,57]. In a preliminary clinical trial, treatment of type 2 diabetic patients with bark extracts of Ficus racemosa resulted in significantly reduced blood glucose levels and increased serum insulin levels [58].

Anti-diabetic effects were shown for Terminalia chebula [59-63] and Syzygium cumini $[26,64,65]$ in normal or diabetes-induced animal models, but not in healthy individuals [66].

\section{Conclusion}

The available clinical data suggesting anti-diabetic activity of plants identified in this survey is limited. Most of the clinical studies lacked sufficient sample size, randomized controlled study design or revealed only low anti-diabetic efficacy following the treatment with plants. In this context, it is also questionable to what extent the numerous anti-diabetic effects of plants and their extracts found in experimental animal and in vitro studies can be extrapolated to human settings. Out of the identified 37 plants used for the treatment of diabetes in Bangladesh only a few were shown to eventually exert anti-diabetic activity in clinical studies.

We henceforth propose to focus future research on the conduction of high-quality clinical studies while concentrating on those plants which show the most promising anti-diabetic efficacy in already performed clinical studies. In this context, it is also of particular interest to include safety issues and to study dose-dependent relationships. There are several other plants identified in this study of potential interest as preliminary data from animal or in vitro studies may indicate some anti-diabetic activity. But this has to be further investigated by clinical trials meeting the requirements of evidence-based medicine [67]. Such studies are of enormous public health interest as they may offer an evidence-based and safe use of non-expensive plant-derived medications against the growing epidemic of diabetes, particularly for lowincome countries such as Bangladesh.

\section{Competing interests}

The authors declare that they have no competing interest to disclose.

\section{Authors' contributions}

SO and MK designed and carried out the survey, analyzed the data and drafted the manuscript. SK recruited the informants, managed the field work and carried out the survey. SHT participated in designing the study and was contact person to administration authorities. $\mathrm{HH}$ participated in designing the study, data analysis and revising the manuscript. All authors read and approved the final manuscript.

\section{Acknowledgements}

The authors wish to thank all local members of Eminence NGO (Dhaka, Bangladesh) and the people involved in the interviews, who made this survey possible. The authors thank the Mirpur diabetic patients group and local authorities in Manikganj for their help and provision of facilities. Special thanks to Dr. Klaus Schümann for his advice, Priya Singh, and Lars Naumann for contributing botanical expertise. This project was funded by the Dr. Leonhard-Lorenz-Stiftung (Technical University of Munich, 85747 Garching, Germany, grant ID: 742/09).

\section{Author details}

${ }^{1}$ Else Kroener-Fresenius-Center for Nutritional Medicine, Klinikum rechts der Isar, 81675 Munich and ZIEL - Research Center for Nutrition and Food Sciences, Technische Universität München, 85350, Freising-Weihenstephan, Germany. ${ }^{2}$ Eminence, 3/6 Asad Avenue, Dhaka 1207, Bangladesh.

Received: 3 August 2012 Accepted: 7 June 2013

Published: 24 June 2013

\section{References}

1. Claquin P: Private health care providers in rural Bangladesh. Soc Sci Med Med Anthropol 1981, 15B:153-157.

2. Bhardwaj SM, Paul BK: Medical pluralism and infant mortality in a rural area of Bangladesh. Soc Sci Med 1986, 23:1003-1010.

3. Ashraf A, Chowdhury S, Streefland P: Health, disease and health-care in rural Bangladesh. Soc Sci Med 1982, 16:2041-2054.

4. Ahmed SM, Hossain MA, Chowdhury MR: Informal sector providers in Bangladesh: how equipped are they to provide rational health care? Health Policy Plan 2009, 24:467-478.

5. Rahman SA, Kielmann T, McPake B, Normand C: Healthcare-seeking behaviour among the tribal people of Bangladesh: can the current health system really meet their needs? J Health Popul Nutr 2012, 30:353-365.

6. Cockcroft A, Andersson N, Milne D, Hossain MZ, Karim E: What did the public think of health services reform in Bangladesh? Three national community-based surveys 1999-2003. Health Res Policy Syst 2007, 5:1.

7. Ahmed SM, Adams AM, Chowdhury M, Bhuiya A: Gender, socioeconomic development and health-seeking behaviour in Bangladesh. Soc Sci Med 2000, 51:361-371.

8. Yusuf M, Wahab MA, Chowdhury JU, Begum J: Ethno-medico-botanical knowledge from Kaukhali proper and Betbunia of Rangamati District. Bangladesh J Plant Taxonomy 2006, 13:15-61.

9. Rahmatullah M, Ferdausi D, Mollik $A H$, Jahan $\mathrm{R}$, Chowdhury MH, Haque WM: A survey of medicinal plants used by Kavirajes of Chalna area, Khulna district, Bangladesh. Afr J Tradit Complement Altern Med 2010, 7:91-97.

10. Rahmatullah M, Mollik AH, Rahman S, Hasan N, Agarwala B, Jahan R: A medicinal plant study of the Santal tribe in Rangpur district, Bangladesh. J Altern Complement Med 2010, 16:419-425.

11. Rahmatullah M, Chakma P, Paul AK, Nasrin D, Ahmed R, Jamal F, Ferdausi D, Akber M, Nahar N, Ahsan S, Jahan R: A survey of preventive medicinal 
plants used by the Chakma residents of Hatimara (south) village of Rangamati district, Bangladesh. Am-Eur J Sustainable Agric 2011, 5:92-96.

12. Kadir MF, Bin Sayeed MS, Shams T, Mia MMK: Ethnobotanical survey of medicinal plants used by Bangladeshi traditional health practitioners in the management of diabetes mellitus. J Ethnopharmacol 2012, 144:605-611.

13. Kadir MF, Bin Sayeed MS, Mia MMK: Ethnopharmacological survey of medicinal plants used by indigenous and tribal people in Rangamati, Bangladesh. J Ethnopharmacol 2012, 144:627-637.

14. Grover JK, Yadav S, Vats V: Medicinal plants of India with anti-diabetic potential. J Ethnopharmacol 2002, 81:81-100.

15. Mukherjee PK, Maiti K, Mukherjee K, Houghton PJ: Leads from Indian medicinal plants with hypoglycemic potentials. J Ethnopharmacol 2006, 106:1-28.

16. Rahim MA, Hussain A, Azad Khan AK, Sayeed MA, Keramat Ali SM, Vaaler S: Rising prevalence of type 2 diabetes in rural Bangladesh: a population based study. Diabetes Res Clin Pract 2007, 77:300-305.

17. Bhowmik B, Binte Munir S, Ara Hossain I, Siddiquee T, Diep LM, Mahmood S, Mahtab $H$, Khan AKA, Hussain A: Prevalence of type 2 diabetes and impaired glucose regulation with associated cardiometabolic risk factors and depression in an urbanizing rural community in bangladesh: a population-based cross-sectional study. Diabetes Metab J 2012, 36:422-432

18. Rahim MA, Azad Khan AK, Nahar Q, Ali SMK, Hussain A: Impaired fasting glucose and impaired glucose tolerance in rural population of Bangladesh. Bangladesh Med Res Counc Bull 2010, 36:47-51.

19. National Institute of Population Research and Training (NIPORT, National Institute of Population Research and Training (NIPORT), MEASURE Evaluation, International Centre for Diarrheal Disease Research, Bangladesh (ICDDR,B), Associates for Community and Population Research (ACPR), 2008: Bangladesh urban health survey 2006. Dhaka: Bangladesh and Chapel Hill, NC, USA; 2008

20. Ayyanar M, Ignacimuthu S: Ethnobotanical survey of medicinal plants commonly used by Kani tribals in Tirunelveli hills of Western Ghats, India. J Ethnopharmacol 2011, 102:243-255.

21. Telefo PB, Lienou LL, Yemele MD, Lemfack MC, Mouokeu C, Goka CS, Tagne SR, Moundipa FP: Ethnopharmacological survey of plants used for the treatment of female infertility in Baham, Cameroon. J Ethnopharmacol 2011, 136:178-187.

22. Zheng X-L, Xing F-W: Ethnobotanical study on medicinal plants around Mt. Yinggeling, Hainan Island, China. J Ethnopharmacol 2009, 124:197-210.

23. Rehecho S, Uriarte-Pueyo I, Calvo J, Vivas LA, Calvo Ml: Ethnopharmacological survey of medicinal plants in Nor-Yauyos, a part of the Landscape Reserve Nor-Yauyos-Cochas, Peru. J Ethnopharmacol 2011, 133:75-85.

24. Mowla A, Alauddin M, Rahman MA, Ahmed K: Antihyperglycemic effect of Trigonella foenum-graecum (fenugreek) seed extract in alloxan-induced diabetic rats and its use in diabetes mellitus: a brief qualitative phytochemical and acute toxicity test on the extract. Afr J Tradit Complement Altern Med 2009, 6:255-261.

25. Hamza N, Berke B, Cheze C, Le Garrec R, Umar A, Agli A-N, Lassalle R, Jové J, Gin $\mathrm{H}$, Moore N: Preventive and curative effect of Trigonella foenumgraecum L. seeds in C57BL/6J models of type 2 diabetes induced by high-fat diet. J Ethnopharmacol 2012, 142:516-522.

26. Pandey $M, A$ : Hypoglycaemic effect of defatted seeds and water soluble fibre from the seeds of Syzygium cumini (Linn.) skeels in alloxan diabetic rats. Indian J Exp Biol 2002, 40:1178-1182.

27. Azad Khan AK, Akhtar S, Mahtab H: Coccinia indica in the treatment of patients with diabetes mellitus. Bangladesh Med Res Counc Bull 1979, 5:60-66.

28. Khan AK, Akhtar S, Mahtab H: Treatment of diabetes mellitus with Coccinia indica. Br Med J 1980, 280:1044.

29. Venkateswaran S, Pari L: Effect of Coccinia indica leaves on antioxidant status in streptozotocin-induced diabetic rats. J Ethnopharmacol 2003 84:163-168.

30. Perez-Gutierrez RM, Damian-Guzman M: Meliacinolin: a potent aglucosidase and a-amylase inhibitor isolated from Azadirachta indica leaves and in vivo antidiabetic property in streptozotocin-nicotinamide -induced type 2 diabetes in mice. Biol Pharm Bull 2012, 35:1516-1524.

31. Bhaskara Rao R, Murugesan T, Sinha S, Saha BP, Pal M, Mandal SC: Glucose lowering efficacy of Ficus racemosa bark extract in normal and alloxan diabetic rats. Phytother Res 2002, 16:590-592.

32. Sophia D, Manoharan S: Hypolipidemic activities of Ficus racemosa Linn. bark in alloxan induced diabetic rats. Afr J Tradit Complement Altern Med 2007, 4:279-288
33. Narender $T$, Khaliq $T$, Singh AB, Joshi MD, Mishra $P$, Chaturvedi JP, Srivastava AK, Maurya R, Agarwal SC: Synthesis of alpha-amyrin derivatives and their in vivo antihyperglycemic activity. Eur J Med Chem 2009, 44:1215-1222.

34. Panda SP, Haldar PK, Bera S, Adhikary S, Kandar CC: Antidiabetic and antioxidant activity of Swietenia mahagoni in streptozotocin-induced diabetic rats. Pharm Biol 2010, 48:974-979.

35. De D, Chatterjee K, Ali KM, Bera TK, Ghosh D: Antidiabetic potentiality of the aqueous-methanolic extract of seed of Swietenia mahagoni (L.) Jacq. in streptozotocin-induced diabetic male albino rat: a correlative and evidence-based approach with antioxidative and antihyperlipidemic activities. Evid Based Complement Alternat Med 2011, 2011:892807.

36. Shibib BA, Khan LA, Rahman R: Hypoglycaemic activity of Coccinia indica and Momordica charantia in diabetic rats: depression of the hepatic gluconeogenic enzymes glucose-6-phosphatase and fructose-1,6bisphosphatase and elevation of both liver and red-cell shunt enzyme glucose-6-phosphate dehydrogenase. Biochem J 1993, 292(Pt 1):267-270.

37. Ali L, Khan AK, Mamun Ml, Mosihuzzaman M, Nahar N, Nur-e-Alam M, Rokeya B: Studies on hypoglycemic effects of fruit pulp, seed, and whole plant of Momordica charantia on normal and diabetic model rats. Planta Med 1993, 59:408-412.

38. Hossain MZ, Shibib BA, Rahman R: Hypoglycemic effects of Coccinia indica: inhibition of key gluconeogenic enzyme, glucose-6-phosphatase Indian J Exp Biol 1992, 30:418-420.

39. Kar A, Choudhary BK, Bandyopadhyay NG: Comparative evaluation of hypoglycaemic activity of some Indian medicinal plants in alloxan diabetic rats. J Ethnopharmacol 2003, 84:105-108.

40. Kamble SM, Kamlakar PL, Vaidya S, Bambole VD: Influence of Coccinia indica on certain enzymes in glycolytic and lipolytic pathway in human diabetes. Indian J Med Sci 1998, 52:143-146.

41. Kuriyan R, Rajendran R, Bantwal G, Kurpad AV: Effect of supplementation of Coccinia cordifolia extract on newly detected diabetic patients. Diabetes Care 2008, 31:216-220.

42. Namsa ND, Mandal M, Tangjang S, Mandal SC: Ethnobotany of the Monpa ethnic group at Arunachal Pradesh. India. J Ethnobiol Ethnomed 2011, 7:31

43. Chaturvedi P: Antidiabetic potentials of Momordica charantia: multiple mechanisms behind the effects. J Med Food 2012, 15:101-107.

44. Miura T, Itoh C, Iwamoto N, Kato M, Kawai M, Park SR, Suzuki I: Hypoglycemic activity of the fruit of the Momordica charantia in type 2 diabetic mice. J Nutr Sci Vitaminol 2001, 47:340-344.

45. Virdi J, Sivakami S, Shahani S, Suthar AC, Banavalikar MM, Biyani MK: Antihyperglycemic effects of three extracts from Momordica charantia. J Ethnopharmacol 2003, 88:107-111.

46. Reyes BAS, Bautista ND, Tanquilut NC, Anunciado RV, Leung AB, Sanchez GC, Magtoto RL, Castronuevo P, Tsukamura H, Maeda K-I: Anti-diabetic potentials of Momordica charantia and Andrographis paniculata and their effects on estrous cyclicity of alloxan-induced diabetic rats. J Ethnopharmacol 2006, 105:196-200.

47. Fuangchan $A$, Sonthisombat $P$, Seubnukarn $T$, Chanouan $R$, Chotchaisuwat $P$, Sirigulsatien $V$, Ingkaninan K, Plianbangchang P, Haines ST: Hypoglycemic effect of bitter melon compared with metformin in newly diagnosed type 2 diabetes patients. J Ethnopharmacol 2011, 134:422-428.

48. Kasbia GS, Arnason JT, Imbeault P: No effect of acute, single dose oral administration of Momordica charantia Linn., on glycemia, energy expenditure and appetite: a pilot study in non-diabetic overweight men. J Ethnopharmacol 2009, 126:127-133.

49. Ooi CP, Yassin Z, Hamid T-A: Momordica charantia for type 2 diabetes mellitus. Cochrane Database Syst Rev 2012, 8, CD007845.

50. Losso JN, Holliday DL, Finley JW, Martin RJ, Rood JC, Yu Y, Greenway FL: Fenugreek bread: a treatment for diabetes mellitus. J Med Food 2009, 12:1046-1049.

51. Kochhar A, Nagi M: Effect of supplementation of traditional medicinal plants on blood glucose in non-insulin-dependent diabetics: a pilot study. J Med Food 2005, 8:545-549.

52. Kassaian N, Azadbakht L, Forghani B, Amini M: Effect of fenugreek seeds on blood glucose and lipid profiles in type 2 diabetic patients. Int $J$ Vitam Nutr Res 2009, 79:34-39.

53. Lu F, Shen L, Qin Y, Gao L, Li H, Dai Y: Clinical observation on trigonella foenum-graecum $L$. total saponins in combination with sulfonylureas in the treatment of type 2 diabetes mellitus. Chin J Integr Med 2008, 14:56-60. 
54. Chattopadhyay RR: A comparative evaluation of some blood sugar lowering agents of plant origin. J Ethnopharmacol 1999, 67:367-372.

55. Khosla P, Bhanwra S, Singh J, Seth S, Srivastava RK: A study of hypoglycaemic effects of Azadirachta indica (Neem) in normaland alloxan diabetic rabbits. Indian J Physiol Pharmacol 2000, 44:69-74.

56. Waheed A, Miana GA, Ahmad SI: Clinical investigation of hypoglycemic effect of seeds of Azadirachta-inidca in type-2 (NIDDM) diabetes mellitus. Pak J Pharm Sci 2006, 19:322-325.

57. Velayutham R, Sankaradoss N, Ahamed KFHN: Protective effect of tannins from Ficus racemosa in hypercholesterolemia and diabetes induced vascular tissue damage in rats. Asian Pac J Trop Med 2012, 5:367-373.

58. Ahmed F, Hudeda S, Urooj A: Antihyperglycemic activity of Ficus racemosa bark extract in type 2 diabetic individuals. J Diabetes 2011, 3:318-319.

59. Sabu MC, Kuttan R: Anti-diabetic activity of medicinal plants and its relationship with their antioxidant property. J Ethnopharmacol 2002 81:155-160.

60. Murali YK, Chandra R, Murthy PS: Antihyperglycemic effect of water extract of dry fruits ofTerminalia chebula in experimental diabetes mellitus. Indian J Clin Biochem 2004, 19:202-204.

61. Rao NK, Nammi S: Antidiabetic and renoprotective effects of the chloroform extract of Terminalia chebula Retz. seeds in streptozotocininduced diabetic rats. BMC Complement Altern Med 2006, 6:17.

62. Murali YK, Anand P, Tandon V, Singh R, Chandra R, Murthy PS: Long-term effects of Terminalia chebula Retz. on hyperglycemia and associated hyperlipidemia, tissue glycogen content and in vitro release of insulin in streptozotocin induced diabetic rats. Exp Clin Endocrinol Diabetes 2007, 115:641-646.

63. Kim J, Hong C-O, Koo Y, Kim S-J, Lee K-W: Oral administration of ethyl acetate-soluble portion of Terminalia chebula conferring protection from streptozotocin-induced diabetic mellitus and its complications. Biol Pharm Bull 2011, 34:1702-1709.

64. Singh N, Gupta M: Effects of ethanolic extract of Syzygium cumini (Linn) seed powder on pancreatic islets of alloxan diabetic rats. Indian J Exp Biol 2007, 45:861-867.

65. Sharma AK, Bharti S, Kumar R, Krishnamurthy B, Bhatia J, Kumari S, Arya DS: Syzygium cumini ameliorates insulin resistance and $\beta$-cell dysfunction via modulation of PPAR, dyslipidemia, oxidative stress, and TNF- $a$ in type 2 diabetic rats. J Pharmacol Sci 2012, 119:205-213.

66. Teixeira CC, Rava CA, Mallman da Silva P, Melchior R, Argenta R, Anselmi F, Almeida CR, Fuchs FD: Absence of antihyperglycemic effect of jambolan in experimental and clinical models. J Ethnopharmacol 2000, 71:343-347.

67. Teixeira CC, Fuchs FD: The efficacy of herbal medicines in clinical models: the case of Jambolan. J Ethnopharmacol 2006, 108:16-19.

doi:10.1186/1746-4269-9-43

Cite this article as: Ocvirk et al.: Traditional medicinal plants used for the treatment of diabetes in rural and urban areas of Dhaka, Bangladesh an ethnobotanical survey. Journal of Ethnobiology and Ethnomedicine 2013 9:43.

\section{Submit your next manuscript to BioMed Central and take full advantage of:}

- Convenient online submission

- Thorough peer review

- No space constraints or color figure charges

- Immediate publication on acceptance

- Inclusion in PubMed, CAS, Scopus and Google Scholar

- Research which is freely available for redistribution 